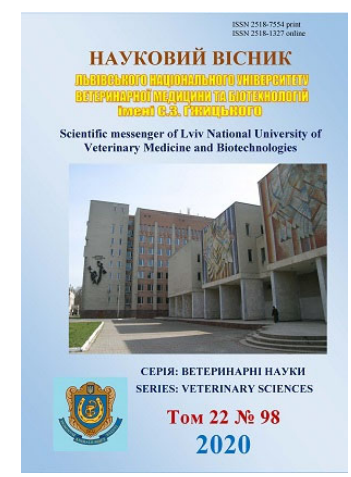

\author{
Науковий вісник Дьвівського національного університету \\ ветеринарної медицини та біотехнологій імені С.3. Гжицького. \\ Серія: Ветеринарні науки \\ Scientific Messenger of Lviv National University \\ of Veterinary Medicine and Biotechnologies. \\ Series: Veterinary sciences
}

\title{
History of development tissue therapy and modern prespectives of it's application in veterinary medicine
}

H. Kalynovskyi, H. Hryshchuk, L. Yevtukh, V. Honcharenko, V. Zakharin, M. Pobirskyi, V. Shnaider

Polissia National University, Zhytomyr, Ukraine

Article info

Received 12.03.2020

Received in revised form 14.04.2020

Accepted 15.04.2020

Polissia National Agroecological University, Korolyova Str., 39.

Zhytomyr, 10025, Ukraine.

Tel. +38-097-746-68-42

E-mail:19vova8@ukr.net
Kalynovskyi, H., Hryshchuk, H., Yevtukh, L., Honcharenko, V., Zakharin, V., Pobirskyi, M., \& Shnaider, V. (2020). History of development tissue therapy and modern prespectives of it's application in veterinary medicine. Scientific Messenger of Lviv National University of Veterinary Medicine and Biotechnologies. Series: Veterinary sciences, 22(98), 28-35. doi: 10.32718/nvlvet9805

Medical products, made of plants, various tissue substrates of animals and humans, have been used for a long time in human and veterinary medicine. Tissue medications of animal origin have been widely used in veterinary science both for prophylactic and therapeutic purposes and as growth factors for fattening of all species. The development of modern biology and some fields of it, human and veterinary medicine in particular, based on the achievements of advanced technologies, provides an opportunity for the appearance of new effective medications in clinical practice. Over time, after the reorganization of the agricultural sector and veterinary medicine as one of its main divisions, tissue medications began to disappear from the range of medical preparations, and they have been almost forgotten and basically not used in recent years. Veterinary medicines market has become overwhelmed with mainly imported synthetic medications and antibiotics. Meanwhile, clinical practice is experiencing an intensive introduction of medications, produced by private factories, which are combinations and mixtures of various existing pharmacological substances. Their annotations indicate a universal and beneficial effect on the body of almost all domestic animals, birds and bees. The paper is aimed at the feasibility study and the restoration necessity of production and use of tissue preparations in veterinary clinical practice. The materials used for the research are the reports published in scientific journals, collections of scientific editions of universities and research establishments, textbooks, newspapers, etc. We have become the first to create tissue medications such as fetoplacentat, made from the uterus and its contents of different pregnancy term of clinically healthy cows, pigs, mares, dogs and cats, and truthenate, made from the larvae of drones aged 5-7 days, for their application in eterinary medicine, obstetrics and gynecology in particular. Production trials of medications carried out on different pregnant animals, have made it possible to identify their corrective effect on the course of pregnancy, childbirth and postpartum period, high preventive activity in the development of functional disorders, subinvolution and inflammatory processes of the genital organs, as well as in the treatment of different forms of infertility in animals and for the improvement of spermatogenesis of male breeders. Further research will focus on the development and implementation of effective methods and measures aimed at elimination of infertility and improvement of the reproduction of farming animals on condition of the use of tissue preparations.

Key words: fetoplacentat, metrofet, truthenate, pregnancy, infertility, spermatogenesis.

\section{Історія розвитку тканинної терапії та сучасні перспективи їі застосування у ветеринарній медицині}

Г. М. Калиновський, Г. П. Грищук, Л. Г. Євтух, В. В. Гончаренко, В. В. Захарін, М. М. Побірський, В. Л. Шнайдер

Поліський національний університет, м. Житомир, Україна 
Виготовлені з рослин, різних тканинних субстратів тварин і людей лікарські засоби здавна застосовують у гуманній та ветеринарній медицині. Великою популярністю користувались і широко застосовувалися тканинні препарати, виготовлені з тканин та органів тварин у ветеринарній медицині не лише з профілактичною і терапевтичною метою, а й як стимулятори росту при відгодівлі всіх видів с.-г. тварин. Розвиток сучасної біології та окремих ї̈ галузей, зокрема гуманної і ветеринарної медицини, щуо базується на досягненнях прогресивних технологій, дає можливість створити ефективні лікарські засоби для використання в клінічній практиці. 3 часом, після реорганізацї аграрної галузі і ветеринарної медицини як одного з головних ї̈ підрозділів, з арсеналу лікарських засобів почали зникати тканинні препарати, а в останні роки про них згадують мало та майже не використовують. Ринок препаратів для ветеринарної медицини заполонили переважно імпортовані синтетичні препарати та антибіотики. Одночасно в клінічну практику інтенсивно впроваджуються виготовлені приватними фірмами лікарські засоби, щзо являють собою комбінаціі та суміші різних існуючих фармакологічних речовин, в анотаціях до яких описується їхня універсальна і корисна дія на організм майже всіх свійських тварин, птиці і бджіл. Метою роботи було проаналізувати в історичному аспекті, обтрунтувати доцільність та необхідність відновлення виготовлення $і$ використання у ветеринарній клінічній практиці тканинних препаратів. Як матеріал для досліджень використані повідомлення, опубліковані в наукових журналах, збірниках наукових видань закладів вищої освіти та науково-дослідних установ, навчальних посібниках, підручниках, газетах тощо. Нами вперше для застосування у ветеринарній медицині, зокрема в акушерстві та гінекології, виготовлений з матки та ї̈ вмісту різного терміну вагітності клінічно здорових корів, свиней, кобил, собак і котів тканинний препарат Фетоплацентат, Метрофет та з личинок 5-7-денних трутнів Трутенат. Виробнича апробація препаратів, проведена на різних вагітних тваринах, дала можливість виявити їх корегувальний вплив на перебіг вагітності, родів і післяродового періоду, високу профілактичну активність щзодо розвитку функціональних порушень, запальних процесів статевих органів, лікування тварин за різних форм неплідності, для підвищення сперматогенезу в самиів-плідників. Подальші дослідження будуть спрямовані на розробку та впровадження ефективних методів $і$ заходів з ліквідаиії неплідності та поліпшення відтворення с.-г. тварин за використання тканинних препаратів.

Ключові слова: Фетоплацентат, Метрофет, Трутенат, вагітність, неплідність, сперматогенез.

Вступ

3 прадавніх часів триває боротьба людей за своє здоров'я та життя. Збереглися друковані записи про використання для лікування найрізноманітніших органів і тканин людей та тварин.

Виготовлені з рослин, різних тканинних субстратів тварин і людей лікарські засоби здавна застосовують у гуманній і ветеринарній медицині. Великою популярністю користувались і широко застосовувались тканинні препарати, виготовлені $з$ тканин і органів тварин у ветеринарній медицині не лише 3 профілактичною та терапевтичною метою, а й як стимулятори росту при відгодівлі всіх видів с.-г. тварин.

Актуальність теми: Розвиток сучасної біології і окремих іiі галузей, зокрема гуманної та ветеринарної медицини, що базується на досягненнях прогресивних технологій, дає можливість створити ефективні лікарські засоби для використання в клінічній практиці (Bushuieva, 2013; Nizamov et al., 2019).

Доцільність виготовлення, способи застосування й ефективність тканинних препаратів у свій час обговорювались на численних наукових конференціях та конгресах. Про застосування тканинних препаратів у галузі тваринництва подавалась інформація у звітних документах державних установ ветеринарної медицини.

3 часом, після реорганізації аграрної галузі та ветеринарної медицини як одного з головних іiі підрозділів, 3 арсеналу лікарських засобів почали зникати тканинні препарати, а в останні роки про них згадують мало і майже не використовують.

Ринок препаратів для ветеринарної медицини заполонили переважно імпортовані синтетичні препарати та антибіотики. Одночасно в клінічну практику інтенсивно впроваджуються виготовлені приватними фірмами лікарські засоби, що являють собою комбінації і суміші різних існуючих фармакологічних речовин, в анотаціях до яких описується їхня універсальна i корисна дія на організм майже всіх свійських тварин, птиці і бджіл (Timoshik \& Duhnitskiy, 2015).

Mета $i$ завдання дослідження - проаналізувати в історичному аспекті, обгрунтувати доцільність та необхідність відновлення виготовлення і використання у ветеринарній клінічній практиці тканинних препаратів.

\section{Матеріал і методи досліджень}

Як матеріал для досліджень використані повідомлення та статистичні дані, опубліковані в наукових журналах, збірниках наукових видань закладів вищої освіти і науково-дослідних установ, навчальних посібниках, підручниках тощо та результати власних досліджень.

Для досягнення мети були використані загальнонаукові методи досліджень: історичний, емпіричний та експериментально-теоретичний (Vazhynskyi \& Shcherbak, 2016).

\section{Результати та їх обговорення}

Аналіз повідомлень 3 різних доступних джерел свідчить, що здавна для лікування людей використовували взяті від померлих кров, печінку, мозок, кістки, жир і піт, від тварин - кістки, роги оленя, слонові кістки, висушених гадюк (Tarasonov, 1985; Selchenok, 1991; Siatynia, 2002; Gritsak, 2003; Rebrik, 2016).

Дослідники з університету Граца, додаючи спермідин в середовище одноклітинних і багатоклітинних організмів, виявили, що дріжджі на живильному середовищі 3 додаванням цього поліаміну живуть у 3-4 рази довше, ніж без нього, а людські імунні клітини майже в три рази. Тривалість життя мушок дрозофіл i мікроскопічних круглих черв'яків при додаванні в їхню їжу спермідину зростала приблизно на 30 відсотків (Eisenberg et al., 2009).

Американські вчені з університету Брауна, досліджуючи пуголовків, встановили, що путресцин вико- 
нує суто захисну функцію при епілептичному нападі. Протягом декількох годин після приступу він перешкоджає активації і руйнуванню нейронів в головному мозку. Результати роботи опубліковані в журналі Nature Neuroscience. У тривалій серії експериментів на моделі епілепсії в пуголовків жаби виявили підвищення рівня путресцин в мозку після приступу. Провідний автор роботи Карлос Айзенман вважає, що подальші дослідження цього механізму допоможуть в розробці нових лікарських препаратів для протиепілептичної терапії у дітей (Bell et al., 2011).

У дослідах на білих мишах за використання тканинних препаратів для вивчення протизапальної дії встановлено, що всі тканинні препарати мали яскраво виражену профілактичну дію, а їхня ефективність склала $72 \%$ (Vostroilova et al., 2018).

Нами вперше для застосування у ветеринарній медицині, зокрема в акушерстві та гінекології, виготовлений з матки та іiі вмісту різного терміну вагітності клінічно здорових корів, свиней, кобил, собак і котів тканинний препарат Фетоплацентат, з фетальної частини плаценти різних видів сільськогосподарських тварин препарат Метрофет та 3 личинок 5-7-денних трутнів - Трутенат (Kalinovskiy et al., 2010; 2011; 2013).

При використанні тканинного препарату “Метрофет” коровам-первісткам за місяць до отелення встановлено, що на 7-у добу після отелення біохімічний склад крові у первісток за фізіологічного перебігу отелення характеризували коливання в фізіологічних межах вмісту глюкози, загального білка, концентрації альбумінів, загального білірубіну, сечовини, креатиніну, ЛФ, холестеролу, тригліцеридів, загального кальцію та неорганічного фосфору.

Отримані результати з підтвердженням клінічними спостереженнями були підставою вважати, що післяотельний період у них перебігав без ускладнень. Порівняно 3 дородовим періодом у корів-первісток без затриманням посліду було виявлено зменшення в крові умісту глобулінів, загального білірубіну, сечовини, креатиніну, ЛФ, холестеролу, тригліцеридів, загального кальцію і неорганічного фосфору, підвищення глюкози, загального білка, концентрації альбумінів, активності АсАТ.

Ці зміни можна обгрунтувати тим, що після народження плоду, як антигенного матеріалу, в материнському організмі знижується в крові концентрація глобулінів. Після народження плода відпадає потреба в інтенсивному скорочені матки, що й обумовлює зниження креатиніну в крові (Zakharin, 2009; Honcharenko, 2011).

Аналізуючи отримані дані з досліду, який передбачав введення “Фетоплацентату”, виявляли збільшення в крові дослідних корів кількості еритроцитів (на 5,2\%), альбумінів (3,1\%) та вмісту гемоглобіну (на $3,8 \%$ ). Вірогідно зростала активність АлАТ (на $61,8 \%$; Р < 0,001). Триразове введення “Фетоплацентату” призводить до вірогідного зниження в крові дослідних тварин кількості лейкоцитів (на 19,8%;
$\mathrm{P}<0,001)$ і активності АсAТ (на 27,0\%; Р < 0,001) (Hryshchuk, 2013).

Комплексне застосування нетелям за місяць до отелення тканинного препарату Фетоплацентат і згодовування суміші мінеральних речовин обумовило у тварин ДГ “Рихальське” підвищення вмісту загального білка у крові на 12,9 \% у першій дослідній групі й на 13,6 \% (Р < 0,001) - у другій, а у ПСП "Україна" на $5,7 \%$ та $5,7 \%(\mathrm{P}<0,05)$ відповідно.

При досліджені білкових фракцій установлено: збільшення вмісту альбумінів у сироватці крові корівпервісток із ПСП “Україна", яким вводили Фетоплацентат, на 4,7 \% і зниження після введення фетоплацентату, сапоніту і сірки - на 3,9 \%, а у ДГ “Рихальське" збільшення в обох дослідних групах на 12,0 i 10,1\% відповідно.

Збільшення концентрації альфа-глобулінів у корівпервісток із ПСП "Україна" у першій дослідній групі на $3,8 \%$, а в другій на 4,9 \%; із ДГ “Рихальське" зниження у першій дослідній групі на 10,3 \%, у другій на $1,1 \%$; у корів-первісток першої дослідної групи із ПСП "Україна" зниження концентрації бетаглобулінів на - 3,7 \%, а в другій - збільшення на 21,1 \%; із ДГ "Рихальське" - зниження і обох групах на 30,3 та 30,9 \% відповідно.

Концентрація гамма-глобулінів у корів-первісток першої дослідної групи із ПСП "Україна" знизилась на 7,5\%, а в другій - на 14,2 \%, із ДГ “Рихальське" збільшилась в обох групах на 17,6 (P < 0,001) та 13,9 \% відповідно.

За результатами дослідження стану імунної системи протягом першої доби після родів у крові корівпервісток із ДГ “Рихальське” - кількість Т-лімфоцитів активних, загальних та хелперів у першій дослідній групі була меншою $(37,15 \pm 0,77-47,46 \pm 1,3-$ $32,62 \pm 1,00 \%)$, ніж у ПСП "Україна" (42,06 $\pm 1,73-$ $52,17 \pm 1,21-38,75 \pm 0,65 \%$ ), Т-лімфоцитів супресорів - більшою у корів-первісток із ДГ "Рихальське" $(16,73 \pm 0,58 \%)$ порівняно з ПСП “Україна” (15,81 \pm $0,60 \%$, але ця різниця невірогідна. Активність фагоцитозу у корів-первісток із ДГ "Рихальське" виявилась меншою $(38,14 \pm 1,22 \%)$, ніж у ПСП "Україна" $(44,37 \pm 2,04 \%)$.

Порівнюючи результати досліджень крові тварин обох господарств за показниками імунного статусу після родів, встановлено: збільшення в крові корівпервісток із ДГ “Рихальське" Т-лімфоцитів активних у першій дослідній групі на 8,8 \% (P < 0,05), а у ПСП "Україна" - на 12,9 \% (P < 0,05); Т-лімфоцитів загальних - на 9,1 \% і 12,5 \% (P < 0,05); Т-лімфоцитів хелперів - на 12,6 \% (P < 0,05) і 21,8 \% (P<0,001) відповідно; в ПСП "Україна" - збільшення Тлімфоцитів супресорів на 18,4 \% тільки в другій дослідній групі; в ДГ “Рихальське" зменшення Тлімфоцитів хелперів у другій групі на 1,3\%, Тлімфоцитів супресорів у першій на 13,0 \% і в другій на - 7,0 \%; у ПСП “Україна” в першій - на 3,7 \%.

Отже, під впливом тканинного препарату Фетоплацентат у первісток в обох господарствах збільшилася кількість Т-лімфоцитів загальних, активних i 
хелперів, що свідчить про стимулювальний вплив тканинного препарату Фетоплацентат на імунний статус тварин (Kalynovskyi et al., 2015).

Ефективність тканинних препаратів, виготовлених 3 тваринної та рослинної сировини, випробовувана на хворих диспепсією телятах. У досліді з 307 тварин,

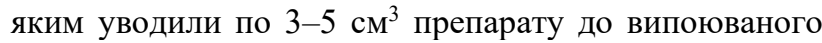
молока та через день давали шлунковий сік по 25$30 \mathrm{~cm}^{3}$ тричі на добу, на четвертий-п’ятий день видужало 291 (94,8 \%) тварин.

У неблагополучних щодо диспепсії господарствах для профілактики захворювання новонародженим телятам теж застосували тканинні препарати. Загальний стан телят поліпшувався, у них нормалізувався гемопоез, поновлювалась лужна рівновага та колірний показник крові (Honcharenko et al., 2019).

Позитивних результатів було досягнуто також при застосуванні тканинних препаратів в поєднанні з антибіотиками при лікуванні диспепсії та гастроентериту телят.

Встановлена висока терапевтична ефективність тканинних препаратів у ветеринарній гінекології при запальних процесах i функціональних порушеннях статевих органів корів. Їх виготовляли 3 печінки, селезінки, сім'яників, яєчників, плаценти, крові і вводили окремо або з іншими препаратами (синестролом, карбохоліном, прозерином). Для лікування тварин за цих хвороб рекомендовані підшкірні ін'єкції суспензії тканинного препарату в дозах: для великої рогатої

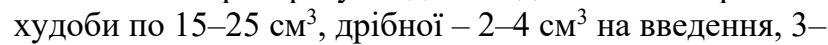
5 разів з інтервалом в 8-12 діб (Hryshchuk, 2012).

Зміни морфологічного і біохімічного складу крові після застосування біологічно активних речовин, які входять до складу тканинних препаратів, з урахуванням клінічного стану тварин можуть бути інформативним матеріалом щодо функціонального стану статевих органів та готовності їх до запліднення.

При хронічному фолікулярному вестибуліті після 1-2-разового введення тканинного препарату вузлики на слизовій оболонці розсмоктувались і лікування, порівняно $з$ іншими засобами, закінчувалось на 3-4 доби раніше. Добрих лікувальних наслідків досягнуто при гострих і хронічних катаральних та катаральногнійних запальних процесах статевих органів за 2-4разового введення 3 інтервалом в 24-48 годин тканинних препаратів у поєднанні з синестролом, карбохоліном або прозерином (Hryshchuk, \& Revunets, 2017).

Тканинні препарати стимулюють моторну функцію матки, сприяють розсмоктуванню потовщених стінок рогів матки, відновленню до 10 доби лікування повноцінних статевих циклів, ефективному осіменінню й нормальному перебігу вагітності.

Дослідами, проведеними на 112 коровах, хворих на хронічний ендометрит із затриманням розсмоктування жовтого тіла в яєчнику, під впливом тканинних препаратів досягли його повного розсмоктування у 32 корів через 8-10 діб, в 56 корів - через 11-14 діб, в 24 корів - через 15-18 діб. У переважної більшості корів стадії збудження статевої охоти і тічки проявля- лися на 10-27-у добу після введення тканинних препаратів. При атрофії яєчників 3 одночасним поліпшенням умов годівлі та утримання 1-2-разове введення препарату сприяло відновленню повноцінних статевих циклів (Prus et al., 2019).

Виробнича апробація препаратів, проведена на різних вагітних тваринах, дала можливість виявити їхній корегувальний вплив на перебіг вагітності, родів та післяродового періоду, високу профілактичну активність щодо розвитку функціональних порушень i запальних процесів статевих органів, лікуванні тварин за різних форм неплідності, для підвищення сперматогенезу в самців-плідників.

Установлено, введення комплексного тканинного препарату, виготовленого з тканин печінки, селезінки та сім'яників (ПСС), бугаям-плідникам у дозі 8 мл на 100 кг живої маси триразово 3 інтервалом 7 днів супроводжувалося відновленням морфофункціонального стану печінки, корегувало сперматогенез у бік збільшення обсягу еякуляту, активності руху сперміїв та їх концентрації в 1 мл.

Через 7 діб після останнього введення препарату в крові тварин в межах норми збільшився вміст загального білка, глобулінів, креатиніну і ЛФ, зменшився альбумінів і сечовини, до верхньої межі норми знизилась активність АлАТ і більше, ніж в два рази АсАТ. Науковці вважали, що ці зміни сталися під впливом тканинного препарату, біологічна активність якого обумовлена наявністю в його складі макро- i мікроелементів та інших біологічно активних речовин. Також доведено, що фільтрат із сім'яників має виражену специфічно спрямовану дію на статеві органи, зокрема чинники локального їх захисту до мікробного фактора. Враховуючи всі досліджувані показники сперми, ефективність тканинного препарату виявлялась у збільшенні кількості заморожених спермодоз протягом застосування - на 44 \%, після закінчення - на 66,7 \% (Kalynovskyi \& Yevtukh, 2014).

Широкого застосування набули тканинні препарати у ветеринарній хірургії, особливо при лікуванні ран і виразок, що довго не загоюються. Препарати застосовували у вигляді суспензії, екстрактів, мазей, порошку, що стимулювало регенеративні процеси в організмі. Мляві грануляції оживлялися, рани та виразки загоювалися без будь-яких втручань у значно коротший час, ніж при інших методах лікування.

Підсадка тваринам шматочків печінки, селезінки або інших тканин після операції сприяє швидкій регенерації та загоюванню ран порівняно з іншими методами лікування.

Високої ефективності досягнуто при лікуванні тканинними препаратами гнійно-некротичних ділянок, зокрема при патологічних процесах в ділянці холки в коней, які важко піддаються іншим методам лікування.

Заслуговують на увагу біостимулятори за гострого перебігу захворювання на екзему. До 70-80 \% тварин при застосуванні тканинних препаратів видужують без будь-якого іншого втручання (Hluhov \& Aralova, 2015). 
Високих показників досягають при застосуванні тканинних препаратів для лікування кератитів і керато-кон'юнктивітів, ран та виразок рогівки. Добре впливають біостимулятори як препарати загальної дії на організм при переломах трубчастих кісток, міозитах, захворюваннях суглобів, а також фурункульозах та інших хворобах (Daricheva \& Ermolaev, 2011).

В. І. Левченко (2002), зауважує, що з 92 елементів, які трапляються в природі, 81 присутній в організмі тварин. Серед них особливе місце та роль відіграють біогенні, що постійно $є$ в організмі тварин у різній кількості (Levchenko et al., 2002).

У тканинному препараті Фетоплацентат за неповного аналізу виявлені: ультрамікроелементи та мікроелементи: Купрум $(0,80 \pm 0,05)$, Плюмбум $(0,06 \pm$ $0,0021)$, Кадмій $(0,03 \pm 0,004)$, Цинк $(2,00 \pm 0,08)$, Манган $(0,10 \pm 0,024)$, Кобальт $(0,04 \pm 0,004)$, Залізо $(8,00 \pm 0,13)$; мікроелементи: Кальцій $(0,19 \pm 0,006)$, Марганець $(0,043 \pm 0,0041)$, Фосфор $(0,008 \pm 0,006)$. За вмістом мінеральних речовин Фетоплацентат та Метрофет є складним комплексом біологічно активних речовин, що доцільно використовувати для введення тваринам як джерела макро- і мікроелементів.

Відмінності складу мінеральних елементів препарату "Метрофет", виготовленого 3 плаценти овець за таких умов утримання і годівлі, на наше переконання, можна пояснити тим, що площа кошар для їхнього моціону велика і вони вигризають траву аж до коренів. Разом з травою із грунту до організму потрапляє i Плюмбум. 3 іншого боку, такий стан пояснюється здатністю плацентарного бар'єру регулювати перехід мінеральних речовин від матері до плода і навпаки. При дослідженні різниці між показниками вмісту Купруму та Феруму в різних препаратах підтверджують літературні дані про те, що Купрум бере активну участь у кровотворенні, посилюючи перетворення Феруму в органічно зв'язану форму, саме тому концентрація Феруму прямо пропорційна до кількості Купруму.

У препараті “Метрофет”, виготовленому із фетальної частини плаценти кобил і корів, також відсутній Цинк, а із плаценти корів - ще й Манган.

Цинк у великих кількостях міститься в гіпофізі, де виробляється пролактин, який впливає на процеси молокоутворення. Тому логічно було б стверджувати, що цей елемент $є$ стимулятором статевої діяльності організму матері. Отже, є всі підстави допустити, що фетальна частина плацентарного бар'єру кобил не затримує Цинк, а корів - Цинк і Манган, тобто вона для них, за певної концентрації в організмі матері, є транзитним пунктом.

Манган впливає на процес кровотворення, особливо у поєднанні з Ферумом, Купрумом та Кобальтом. Також він тісно пов'язаний із відтворювальними функціями. Всмоктування та обмін Мангану в материнському організмі з плодом уповільнюється за надлишку Кальцію та Фосфору.

Таким чином, дослідження елементного складу тканинних препаратів дозволяє поетапно простежити проникнення мінеральних елементів через плаценту до плода та надає можливість виявити найбільш критичні періоди розвитку тварин. На основі отриманих даних проводити цілеспрямовану корегувальну терапію при веденні тваринництва в сучасних екологічних умовах Полісся України (Kalynovskyi et al., 2009; Goncharenko, 2017).

Допускаємо, що розширення та поглиблення досліджень дасть можливість виявити в Фетоплацентаті та Метрофеті всі наявні в організмі тварин мінеральні речовини.

У гуманній та ветеринарній медицині набули широкого використання препарати, виготовлені з продуктів бджільництва: меду, прополісу, перги, обніжжя.

При використання тканинного препарату Трутенат через тиждень після закінчення досліду в крові корів другої групи виразно змінився в бік збільшення рівень загального білка $(77,28 \pm 3,02-80,22 \pm 1,83 г / л)$, альбумінів $(35,81 \pm 1,04-47,5 \pm 0,90 \%)$, загального білірубіну $(5,38 \pm 0,75-6,98 \pm 0,53$ мкмоль/л), сечовини $(3,67 \pm 0,12-4,12 \pm 0,25$ ммоль/л), АлАТ $(17,80 \pm 1,12$ - 20,61 \pm 3,59 Од/л) і АсАТ (54,00 \pm 4,82 - 66,21 \pm 4,86 Од/л), в бік зменшення - креатиніну $(115,44 \pm$ $8,75-97,38 \pm 6,19$ мкмоль/л) та лужної фосфатази $(158,69 \pm 14,48-101,76 \pm$ 4,71 Од/л). Концентрація загального кальцію і неорганічного фосфору теж змінювались в незначних межах, але співвідношення між ними залишилось майже незмінним (1,7:1 - 1,6:1).

Також змінився у фізіологічних межах склад крові корів першої дослідної групи за введення їм фетоплацентату: збільшився рівень загального білірубіну $(5,01 \pm 0,34-8,00 \pm 0,63$ мкмоль/л), сечовини $(3,97 \pm$ $0,23-4,28 \pm 0,31$ ммоль/л) та активність АлАТ $(19,18 \pm 2,18-21,60 \pm 6,62$ Од/л) і АсAТ $(60,99 \pm 4,97$ - 67,60 $\pm 7,95$ Од/л), зменшився - креатиніну $(114,02 \pm 8,73-102,66 \pm 3,84$ Од/л), до однакового рівня зріс уміст альбумінів $(47,60 \pm 2,38$ та 47,51 \pm 0,90 г/л), сечовини (4,29 $\pm 0,31$ та 4,12 $\pm 0,25$ ммоль/л), та холестерину $(3,54 \pm 0,22$ та 3,54 $\pm 0,22$ ммоль/л).

Оскільки збільшення і зменшення після введення препарату досліджуваних показників крові відбулося в фізіологічних межах, то є підстава стверджувати про корегувальний вплив Фетоплацентат-К та Трутенат-Д на інтенсивність обміну речовин в організмі тільних корів.

Підвищення активності АсАТ в обох групах корів до початку досліду вказує на порушення функції печінки, що виникло під дією складників раціону, зокрема впливу комплексної мінеральної добавки.

Збільшення активності АсАТ у крові корів після закінчення досліду в обох випадках не є наслідком застосування препаратів, а показником наростаючого порушення функції печінки, що зумовлений впливом мінеральної добавки.

Трутенат стимулює інтенсивність перебігу всіх стадій отелення, що проявляється завершенням стадії виведення плода протягом 45-50 хвилин, послідової$480 \pm 35$ хвилин. Стан новонароджених телят від корів, яким вводили Трутенат, характеризувався коливанням у властивих для даної породи абсолютних промірів анатомічних ділянок тіла. Маса новонаро- 
джених становила 29,80 $\pm 0,97-27,60 \pm 1,81$ кг, вони піднімались через 42-36 хвилин, смоктальний рефлекс та пошук вимені наставав протягом 45 хвилин (Prus \& Krut, 2016).

Таким чином, можна констатувати, що під впливом сучасних тканинних препаратів відбувалося збільшення, порівняно 3 вихідними даними, окремих складників крові. Ці зміни дають підставу стверджувати, що під дією вказаних препаратів в організмі відбувається активація і корекція перебігу окремих біохімічних процесів.

У зв'язку з наведеним, у нас виникає певний сумнів щодо впровадження нанотехнології у ветеринарній медицині як способу вирішення нагальних проблем теорії та практики, що стосуються підвищення резистентності тваринного організму, лікування окремих і групових захворювань, ранової патології. Для чого конструювати шляхом найскладніших технологій препарати, до складу яких входять у різних дозах, доведених до фізіологічних параметрів організму, речовини, якщо в тканинних препаратах Фетоплацентат, Метрофет, Трутенат вони присутні. Питання лише в розумному і обгрунтованому його застосуванні.

\section{Висновки}

Людство $з$ давніх-давен використовувало препарати, виготовлені 3 різних органів і тканин, 3 метою лікування та профілактики захворювань різної етіологіï. Саме тому сфера застосування тканинної терапії постійно розширюється, оскільки цьому сприяє встановлений факт посилення дії лікарських засобів у поєднанні їх із тканинними препаратами.

Тканинні препарати Фетоплацентат, Метрофет i Трутенат, виготовлені за методом В. П. Філатова в модифікації кафедри акушерства і хірургії ЖНАЕУ, перспективні засоби для лікування та профілактики хвороб тварин, зокрема за умов ведення органічного виробництва.

Перспективи подальших досліджень. Подальші дослідження будуть спрямовані на розробку та впровадження ефективних методів, схем і заходів лікування та профілактики хвороб тварин 3 використанням тканинних препаратів.

\section{References}

Bell, M. R., Belarde, J. A., Johnson, H. F., \& Aizenman, C. D. (2011). A neuroprotective role for polyamines in a Xenopus tadpole model of epilepsy. Nature Neuroscience, 14(4), 505-512. doi: 10.1038/nn.2777.

Bushuieva, I. V. (2013). Marketynhovi doslidzhennia rozvytku rynku veterynarnykh preparativ ta oblasti veterynarnoi farmatsii [Marketing research on the development of the veterinary market and the field of veterinary pharmacy]. Zaporozhskyi medytsynskyi zhurnal. Ser. Voprosi farmatsyy, 3(78), 90-93. http://nbuv.gov.ua/UJRN/Zmzh_2013_3_25 Ukrainian).
Daricheva, N. N., \& Ermolaev, V. A. (2011). Tkanevaya terapiya $\mathrm{v}$ veterinarnoy meditsine: monografiya. [Tissue therapy in veterinary medicine: a monograph]. Ulyanovsk: UGSHA (in Russian).

Drach, O. O., \& Borysenko, N. M. (2018). Istoriia medytsyny i farmatsii (vid naidavnishykh chasiv do seredyny XVII st.): navchalnyi posibnyk. [History of medicine and pharmacy (from ancient times to the middle of the 17th century): Tutorial]. Cherkasy: vydavets Chabanenko Yu. A. (in Ukrainian).

Eisenberg, T., Knauer, H., Schauer, A., Büttner, S., Ruckenstuhl, C., Carmona-Gutierrez, D., Ring, J., Schroeder, S., Magnes, C., Antonacci, L., Fussi, H., Deszcz, L., Hartl, R., Schraml, E., Criollo, A., Megalou, E., Weiskopf, D. Laun, P., Heeren, G., Breitenbach, M., Grubeck-Loebenstein, B., Herke,r E., Fahrenkrog, B. \& Madeo, F. (2009). Induction of autophagy by spermidine promotes longevity. Nature Cell Biology, 11, 1305-1314. doi: 10.1038/ncb1975.

Goncharenko, V. V. (2017). Sklad tkanynnykh preparativ, vyhotovlenykh metodom V. P. Filatova [Composition of tissue preparations made by V. P. Filatov method]. Tvarynnytstvo Ukrainy, 40-33 (in Ukrainian).

Gritsak, E. N. (2003). Populyarnaya istoriya meditsinyi [Popular medical history]. Moskva. https://books.google.com.ua/books/about/Популярная _история_ме.html?id=YbDBAAAAQBAJ\&redir_esc $=\mathrm{y}$ (in Russian).

Hluhov, A. A., \& Aralova, M. V. (2015). Patofiziologiya dlitelno nezazhivayshih ran I sovremennyie metodyi stimulayatsii ranevogo protsessa [Pathophysioligia of non-healing wounds and modern methods of stimulation of the wound process]. Novosti Khirurgii, novdec, 23(6), 673-679. doi: 10.18484/23050047.2015.6.673 (in Russian).

Honcharenko, V. V. (2011). Kliniko-symptomatychne i patohenetychne obgruntuvannia profilaktyky neplidnosti koriv-pervistok [Clinical-symptomatic and pathogenetic substantiation of prevention of infertility of first-born cows] (Avtoreferat dysertatsii kandydata veterynarnykh nauk), Sumy (in Ukrainian).

Honcharenko, V. V., Hryshchuk, H. P., \& Sheremet, S. I. (2019). Stan obminu rechovyn u sukhostiinykh koriv, yak osnova obgruntuvannia profilaktyky i likuvannia teliat za shlunkovo-kyshkovykh zakhvoriuvan. [State of metabolism of cows at dry period as the basis for reasoning of prevention and treatment of calves with gastrointestinal diseases]. Naukovyi visnyk LNUVMB, 21(93), 53-59. doi: 10.32718/nvlvet9310 (in Ukrainian).

Hryshchuk, H. P. (2012). Vplyv fetoplatsentatu ta estrofanu na vidtvoriuvalnu funktsiiu koriv [Influence of fetoplacental and estrophan on reproductive function of cows]. Veterynarna medytsyna Ukrainy, 2(192), 21-23. http://ir.znau.edu.ua/bitstream/123456789/ 2312/6/Vet.\%20m.\%20_2012_21-23.pdf (in Ukrainian).

Hryshchuk, H. P. (2013). Patohenetychne obgruntuvannia profilaktyky symptomatychnoi neplidnosti koriv na tli zatrymannia poslidu [Pathogenetic substantiation of 
prevention of symptomatic infertility of cows against the backdrop of delayed litter] (Avtoreferatdysertatsiikandydataveterynarnykhnauk), Sumy (in Ukrainian).

Hryshchuk, H. P., \& Revunets, A. S. (2017). Zastosuvannia tkanynnoi terapii $\mathrm{u}$ borotbi $\mathrm{z}$ symptomatychnoiu neplidnistiu koriv [Use of tissue therapy to combat symptomatic infertility of cows ]. Visnyk ZhNAEU, 2(63), 3, 37-44 (in Ukrainian).

Kalinovskiy, G. M., Hryshchuk, H. P., Revunets, A. S., Kovalchuk, Yu. V., Karpyuk, V. V., Kovalov, P. V., Zaharin, V. V., Afanasieva, L. P., \& Zhuravlov, V. D. (2010). Patent Ukrainy 89579. Kyiv: Derzhavne vidomstvo Ukrainy. http://ir.znau.edu.ua/handle/ 123456789/4834 (in Ukrainian).

Kalinovskiy, G. M., Omelyanenko, M. M., Hryshchuk, H. P., Goncharenko, V. V., Afanasieva, L. P., Lutay, I. Yu., Krut, S. I., Revunets, A. S., Karpyuk, V. V., Kovalchuk, Yu. V., Kovalov, P. V., Chuprun, L. O., \& Zaharin, V. V. (2013) Patent Ukrainy 80879. Kyiv: Derzhavne vidomstvo Ukrainy. http://ir.znau.edu.ua/ handle/123456789/4835 (in Ukrainian).

Kalinovskiy, G. M., Revunets, A. S., Afanasieva, L. P., Goncharenko, V. V., Chuprun, L. O., Lutay, I. Yu., Omelyanenko, M. M., \& Zhuravlov, V. D. (2011). Patent Ukrainy 93839. Kyiv: Derzhavne vidomstvo Ukrainy. http://ir.znau.edu.ua/handle/123456789/3205 (in Ukrainian).

Kalynovskyi, H. M., \& Yevtukh, L. H. (2014). Vplyv kompleksnoho tkanynnoho preparatu na biokhimichnyi sklad krovi ta yakist spermy buhaiv-plidnykiv. [The effect of complex tissue preparation on the biochemical composition of blood and the quality of sperm of booger-suckers]. Problemy zooinzhenerii ta veterynarnoi medytsyny, 28(2), 486-489. http://nbuv.gov.ua/UJRN/pzvm_2014_28\%282\%29_ 107 (in Ukrainian).

Kalynovskyi, H. M., Revunets, A. S., \& Hryshchuk, H. P. (2009). Hormonalnyi ta mikroelementnyi sklad tkanynnoho preparatu fetoplatsentatu, vyhotovlenoho z matky riznykh vydiv tvaryn. [The hormonal and microelement warehouse of the tissue preparation fetoplacentate, the prepared uterus of the uterine species of the creature]. Naukovyi visnyk NUBIP, 136, 76-81 (in Ukrainian).

Kalynovskyi, H. M., Zakharin, V. V., \& Afanasiieva, L. P. (2015). Efektyvnist zastosuvannia tkanynnoho preparatu fetoplatsentatu dlia profilaktyky i likuvannia akusherskykh ta hinekolohichnykh patolohii u koriv. [Efficacy of the use of tissue preparation fetoplacentate for the prevention and treatment of obstetric and gynecological pathologies in cows] Naukovotekhnichnyi biuleten Derzhavnoho naukovodoslidnoho kontrolnoho instytutu veterynarnykh preparativ ta kormovykh dobavok i Instytutu biolohii tvaryn, 16(2), 372-379. http://nbuv.gov.ua/UJRN/ Ntbibt_2015_16_2_63 (in Ukrainian).

Levchenko, V. I., Vlizlo, V. V., Kondrakhin, I. P., \& Tsvilikhovskyi, M. I. (2002). Veterynarna klinichna biokhimiia. [Veterinary Clinical Biochemistry: Tutorial]. Bila Tserkva: BNAU (in Ukrainian).
Nizamov, R. N., Koniukhov, H. V., Sharyfullyna, D. T., Tytov, A. S., \& Shakurov, M. M. (2019). Radiozaschitnyiy effekt veschestv zoogennogo proishozhdeniya farmatsiyi [Radioprotective effect of substances of zoogenic origin]. Veterinarnyiy vrach, 2, 62-66. doi: 10.33632/1998-698X.2019-2-62-67 (in Russian).

Prus, V. N., \& Krut, S. Y. (2016). Vlyianye tkanevih preparatov "Fetoplatsentat-K" i "Trutenat-D" na techenie stelnosty, otela, posleotelnoho peryoda y sostoianye novorozhdennih telyat [Influence of tissue preparations "Fetoplacentat-K" and "Truthenat-D" on the course of pregnancy, calving, postpartum period and condition of newborn calves]. Uchenyie zapiski uchrezhdeniya obrazovaniya "Vitebskaya ordena "Znak Pocheta" gosudarstvennaya akademiya veterinarnoy meditsinyi": nauch.- prakt. zhurn, 52(1), 74-77 (in Russian).

Prus, V. M., Sheremet, S. I., Zaharin, V. V., \& Honcharenko, V. V. (2019). Efektyvnist vykorystannia tkanynnoho preparatu Metrofet $\mathrm{M}$ dlia synkhronizatsii statevoi okhoty u koriv [Efficiency of using Metrofet $\mathrm{M}$ tissue preparation for synchronization of sexual hunting in cows]. Tvarynnytstvo Ukrainy, 2, 20-23. http://ir.znau.edu.ua/handle/123456789/9640 (in Ukrainian).

Rebrik, V. V. (2016). Drevneegipetskaya magiya i meditsina [Ancient Egyptian magic and medicine ]. SanktPeterburg. https://www.twirpx.com/file/1883304 (in Russian).

Selchenok, K. (1991). Taynyi vostochnoy meditsinyi [Secrets of Oriental Medicine]. Minsk (in Russian).

Siatynia, M. L. (2002). Istoriia farmatsii: navch. posib. [History of Pharmacy: Tutorial ]. Lviv (in Ukrainian).

Sorokina T. S. (1983). Meditsina v Drevnem Rime. [Medicine in Ancient Rome]. Feldsher i akusherka, 12, 3843. (in Russian).

Sorokina, T. S. (1994). Istoriya meditsinyi farmatsiyi [The history of medicine]. Moskva (in Russian).

Tarasonov, V. M. (1985). Simvolyi meditsinyi kak otrazhenie vrachevaniya drevnih narodov [Symbols of medicine as a reflection of the healing of ancient peoples]. Moskva (in Russian).

Timoshik, Yu. V., \& Duhnitskiy, V. B. (2015). Suchasnyi stan rynku veterinarnih likarskih zasobiv v Ukrayini. [Current status of veterinary medicines market in Ukraine]. Naukoviy visnik NUBIP. Ser. Veterinarna meditsina, yakist i bezpeka produktsiyi tvarinnitstva, 221, 130-135. http://nbuv.gov.ua/UJRN/nvnau_vet_ 2015_221_27 (in Ukrainian).

Vazhynskyi, S. E., \& Shcherbak, T. I. (2016). Metodyka ta orhanizatsiia naukovykh doslidzhen: Navch. posib. [Methodology and organization of scientific research: Tutorial] Sumy: SumDPU im. A. S. Makarenka (in Ukrainian).

Vostroilova, H. A. et al. (2018). Izuchenie protivovospalitelnogo dejstvija tkanevyh preparatov na belyh myshah [Study of anti-inflammatory action of tissue preparations in white mice] Veterinarnyj 
Farmakologicheskij Vestnik, 3, 40-45. and postpartum period in first-born cows] (Avtoreferat doi: 10.17238/issn2541-8203.2018.3.40 (in Russian). dysertatsii kandydata veterynarnykh nauk), K. (in

Zakharin, V. V. (2009). Perebih rodiv ta pisliarodovoho Ukrainian). periodu $\mathrm{u}$ koriv-pervistok [The course of childbirth 